\title{
SlavaSnowShow - atrás da cortina, a tradição em meio à superprodução
}

JOICE AGLAE BRONDANI

Professora colaboradora do PPGA-UFU, através do PRODOC-CAPES. Doutora pelo PPGAC-UFBA (intercâmbio Università di Roma Tre e Scuola Sperimentale del'Attore-ITA). Mestre pelo PPGAC-UFBA (intercâmbio Université Paris X - França). Fundadora da Cia Buffa de Teatro (Brasil) e Bottega Buffa CircoVacanti (Itália). Atriz e diretora teatral. Idealizadora do projeto de pesquisa "Teatro-Máscara-Ritual" (2010-). 


\section{- RESUMO}

O presente artigo não vem levantar grandes reflexões, nem conceitos sobre a Máscara do clown ou técnicas dessa arte. Ele vem relatar a experiência dessa pesquisadora/atriz/diretora teatral dentro do espetáculo SlavaSnowShow, dirigido e interpretado por Viatcheslav Polounine (Slava). A partir das experiências, surgem reflexões e relativizações sobre diferentes práticas e vivências dentro dessa arte, além de trazer uma percepção sobre a convivência do grupo de atores e equipe técnica do espetáculo, uma superprodução que carrega traços de uma tradição circense.

\section{- PALAVRAS-CHAVE}

Clown, técnica, tradição, contemporaneidade.

\section{- RÉSUMÉ}

Cet article ne cherche pas à évoquer des réflexions ou des concepts à propos du masque ou des techniques du clown; il parle de l'expérience de la chercheuse, actrice et metteur en scène qui a fait partie du SlavaSnowShow, spectacle réalisé et joué par Polounine Viatcheslav (Slava) et son groupe. Cette expérience a fait mûrir une refléxion sur les différentes pratiques de cet art. Elle a également mis en lumière un esprit de groupe au sein de la troupe de comédiens et de techniciens sur une grande production, portant en elle les traits d'une tradition du cirque.

- MOTS-CLÉS

Clown, technique, tradition, contemporanéité.

SlavaSnowShow é um espetáculo que comove. Apresenta a solidão do ser humano, o inverno que habita a alma humana, o vento frio e seco que congela nariz, orelhas, pés e mãos. Não há agasalho ou cobertor que aqueça o frigorífico coração do Homem. São essas as conclusões que tive, depois de assistir ao espetáculo. Ou, talvez, tudo isso foi o que pensei durante o espetáculo, pois, no final, após uma nevasca de papel picado, que sai do palco em direção a plateia, invadindo o público, acontece uma pausa, as luzes se acendem e a plateia é invadida por bolas de diversos tamanhos e cores, jogadas pelos palhaços para os espectadores brincarem. Com isso, o espetáculo ganha leveza pueril e o público se diverte como na infância, jogando bolas. E ali, adultos e crianças, permanecem brincando, até que os clowns se tornam espectadores do público. Certamente, o público sai do teatro com a última sensação, mas também é certo que, na lembrança, fica um resquício da imagem do rude inverno que habita aquela Humanidade clownesca, espelho da solidão que abala a sociedade. 


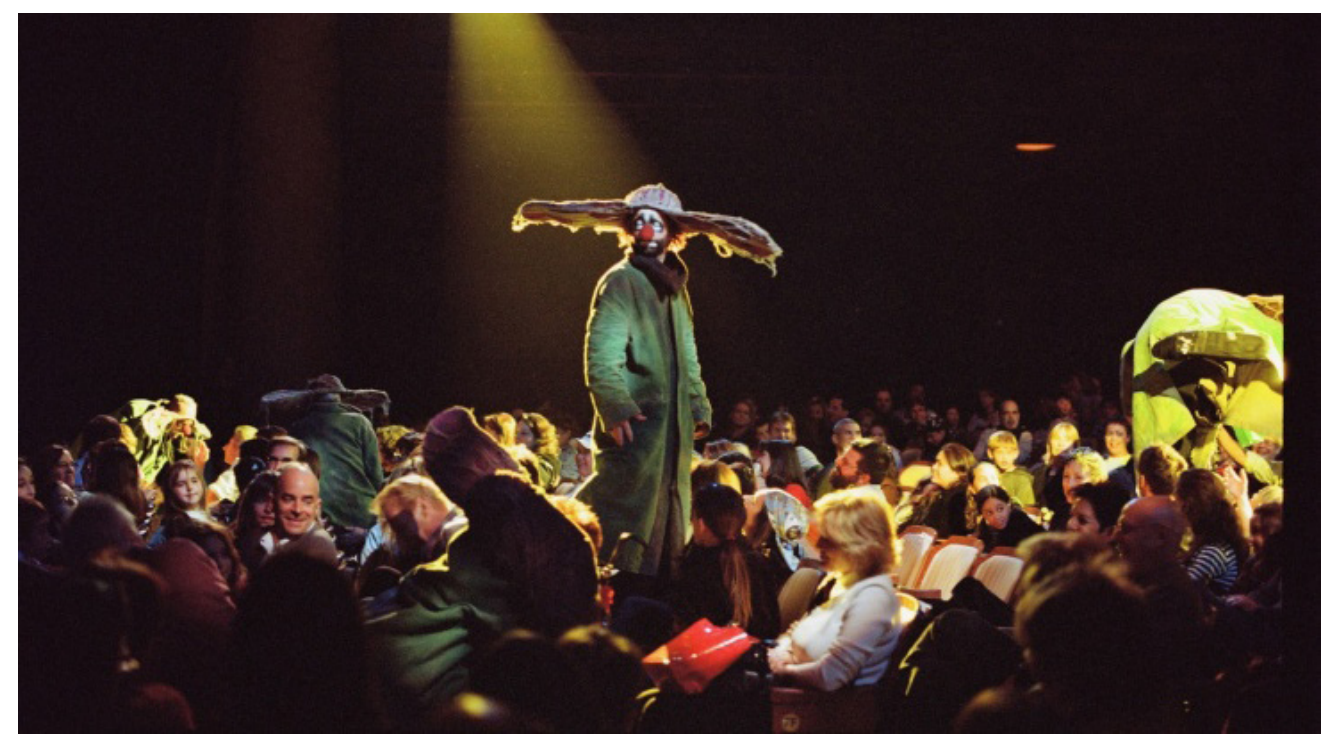

Figura 1 - Direitos reservados - Espetáculo: SlavaSnowShow

Cena: Entract. Fonte:

Para quem assistiu ao espetáculo, a sensação da brincadeira e do divertimento pode ser que tenha permanecido, mas, se observarmos com delicadeza e cuidado o olhar triste do primeiro clown que entra em cena, vestido de amarelo e carregando uma corda, a qual prepara para se enforcar, talvez comece a reconhecer tamanho sentimento de solidão, e a se reconhecer naquele clown. O espetáculo nada tem de alegre, muito menos de leve, apresenta um lado sombrio da humanidade, de um modo que pode parecer jocoso, mas é muito mais cruel que engraçado.

Esse artigo é, na verdade, uma espécie de relato e reflexão sobre minha primeira experiência enquanto atriz dentro do espetáculo SlavaSnowShow. Não se trata de um artigo que segue os impulsos da experiência vivida no grupo ou na cena, mas também o que está por trás do espetáculo. O que pude vivenciar é uma grande relação com a tradição circense, que não se perde, mesmo dentro de uma super produção como se tornou SlavaSnowShow.

Para não começar sem nenhuma referência a não ser a do espetáculo, contextualizo um pouco sobre o clown em questão ${ }^{1}$, Viatcheslav Polounine, ou, como o conhecemos, "Slava", e a sua busca em direção a sua arte, a qual não foi um caminho curto ou fácil. Polounine chegou em 1967 em Leningrado, formou-se em Economia e História da Arte, porém, perseguiu outra formação, a de mimo - a qual obteve seguindo os passos de Marcel Marceau e outros, em modo muito específico e autodidático. Sua preferência em não utilizar texto em seus espetáculos, a meu ver, pode vir de um fato real. Como ator, não foi aceito no Instituto Teatral de Leningrado por não ter uma boa dicção. Tal qual um clown, não desistiu. Entre cambalhotas e sobressaltos, foi atrás de uma formação autêntica, não em uma escola tradicional, mas acompanhando, observando e estudando seus mestres: Marceau, Chaplin, Keaton e outras excelências do mimo e do cinema mudo.

\footnotetext{
O leitor poderá obter mais informações sobre a formação e caminho traçado por Slava, no artigo de PICON-VALLIN, Bèatrice, nessa mesma revista, entitulado "O renascimento de uma cultura perdida". 
É possível perceber a autenticidade e as variadas referências, nos números/cenas que Slava cria para os espetáculos - um humor específico, surrealismo, poesia e grande rigorosidade técnica e de disciplina, a qual se quebra após o conhecimento adquirido. Tal qual na commedia dell'arte, as partituras devem ser feitas com exímia precisão, para depois ganharem o frescor da aparente improvisação e espontaneidade.

No dia nove de novembro de 2011, através da amigável apresentação feita pela Drâa Bèatrice Picon-Vallin, fui recebida por Slava e sua família em seu castelo amarelo, situado nas redondezas de Paris. Nesse primeiro contato, introduzido pela Doutora Picon-Vallin, Slava me convidou para participar como atriz, com sua trupe, na próxima temporada em Paris, do dia 29 de novembro ao dia 31 de dezembro de 2011, no teatro Trianon.

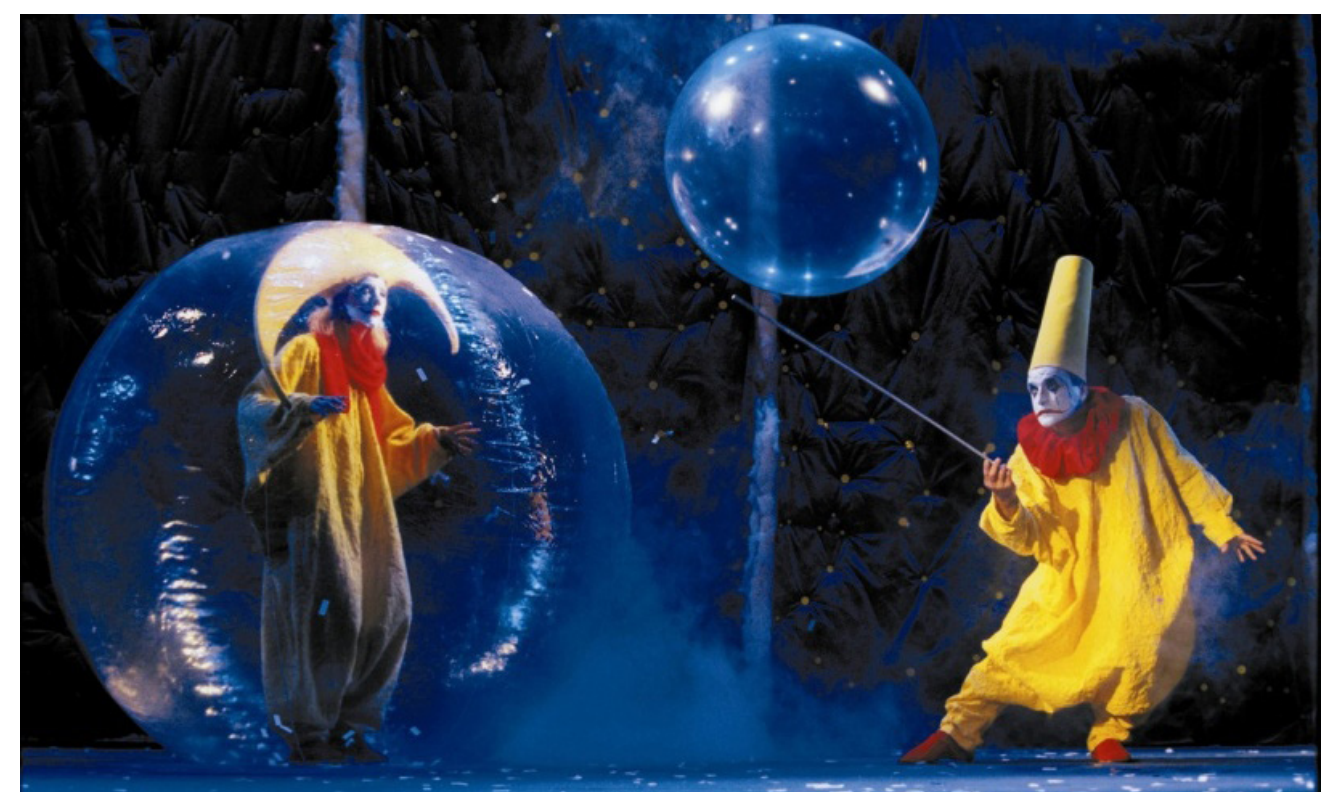

Figura 2 - Direitos reservados - Espetáculo: SlavaSnowShow. Fonte: ........

Uma viagem urgente de retorno ao Brasil para reorganização, e, no dia 27 de novembro, estava de volta à Paris. Nesse meio tempo permaneci em contato com a secretária Anna Hannik, via e-mail, para organizar minha participação no espetáculo.

A temporada começava dia 29 de novembro, com uma sessão às 20horas. Primeira surpresa e aprendizado: através de um e-mail da secretária de Slava, fui avisada que me encontraria com Slava e a trupe, somente, no dia 29, às $11 \mathrm{~h}$.

Apesar de, nos e-mails, sempre perguntar o que deveria levar para o teatro (maquiagem, roupa de trabalhotraining), as respostas nunca me foram dadas.

No dia 29, cheguei ao Trianon alguns minutos antes da hora marcada, entrei pelos fundos do teatro. Fui recebida pela secretária Anna e pela esposa de Slava, Elena. $\mathrm{Na}$ época, Anna não falava muito francês, Elena falava mais que Anna e a comunicação acontecia por meio de um estranho francês fragmentado. Elena me mostrou o teatro e depois me levou até o restaurante do teatro, reservado para as refeições dos atores, e me apresentou para o grupo. Durante o almoço a comunicação era limitada, pois falavam sempre em russo, tentando, em alguns poucos momentos falarem em francês. No entanto, para mim, ficar sem falar ou encontrar outros modos de comunicação, nunca foi um problema (devido ao meu próprio histórico), então, tudo era experiência. 
Após o almoço, descemos ao camarim. Elena me entregou o figurino, apresentou Tatiana Karamysheva, e pediu que ela me ensinasse a maquiagem. Em um francês fragmentado e com sotaque russo, Tatiana (atriz maravilhosa e generosa em cena) me disse, mostrando os olhos, blanche, blanche et noir, depois me mostrando a boca blanche et noir - a parte de dentro dos olhos era branca e o contorno, preto. $\mathrm{O}$ mesmo valia para a boca. A parte preta da maquiagem era feita com uma esponja que, vista ao longe, imitava a textura de uma barba por fazer e olheiras. Depois, Elena e Slava me perguntaram se eu conhecia o espetáculo, e respondi que sim. Tinha assistido na Itália. Então, me disseram para estar no palco às 19h e 45min, preparada, isto é, vestida e maquiada.

Eu aguardava no corredor, segurando minhas roupas. Atores entravam e saiam, todos falando em russo. Por volta das $17 \mathrm{~h}$, todos subiram para o refeitório, mas permaneci no corredor esperando que me dissessem o que deveria fazer e onde era meu lugar no camarim, pois tinha percebido que todos tinham seus lugares específicos e alterar a ordem sem ser convidada, não seria bem visto. Pelo pouco que já tinha observado das relações, percebi que agiam como uma família e quem não possuía parentesco consanguíneo, mas que tinha conquistado a confiança deles, passava a ser parte da família também.

Essa família tem hierarquias, como todas, e é de constituição matriarcal. Tudo passa por Elena, um braço forte e firme dentro da instituição-empresa-família SlavaSnowShow. Ao meu ver, essa constituição familiar, ainda herdada do mundo circense, é um modo de se protegerem e se fortalecerem e, de certa forma, isso amedronta quem chega, principalmente alguém que foi introduzida por uma pessoa que Ihes é muito cara - como Béatrice Picon-Vallin. Tenho natureza introvertida, primeiro observo tudo e, somente se me sinto à vontade, começo a me relacionar de modo mais descontraído, uma ação-reação de defesa minha.

Coloquei minha roupa de ensaio, pois, para mim, é natural alongar e aquecer antes do trabalho, e permaneci no corredor. Não fui ao restaurante, pois não tinha a mínima vontade de comer, um novo espetáculo é sempre "uma nova experiência" e estava tão excitada e emocionada com o espetáculo, que meu estômago não conseguiria digerir nada, além disso, como de costume, não consigo comer antes das apresentações. Então, permaneci no corredor. Depois de um tempo, os atores retornaram do restaurante. $\mathrm{O}$ ator Sasha Fritz/Fritz Alexander se aproximou e se apresentou. Ele mora em Paris hà mais tempo e fala francês perfeitamente. Sasha mostrou onde seria meu lugar no camarim e me apresentou a outro ator, Artem Zhimo, que faz a dupla com Salva em algumas cenas. Vendo fotos de Polounine jovem, Artem se assemelha muito a ele. Artem me emprestou um nariz, pois todos possuem o mesmo figurino e formato de máscara. Sasha me apresentou a quase todos os atores: Roberto Saralp, Oleg Sosnovikov, Oleg, Lugovskoy, Zhenya Perevalov, Yuory Musatov, Stanislav Varkki. Todos eram muito atenciosos. Apesar da falta da língua falada (eu não falo russo e a maioria deles não falam francês), a comunicação existia, porque outra linguagem se instaurava. Ao perceber que eu não possuía nada para fazer a maquiagem, Roberto Saralp me emprestou as esponjas e Tatiana, a maquiagem. E me disse claramente "amanhã você compra a sua" - cada um dos atores tinha o seu próprio estojo de maquiagem e eu deveria ter o meu. Fiquei me questionando: se sempre perguntei nos e-mails o que deveria levar para o teatro, porque nunca me responderam? Me senti constrangida em pedir tudo para os outros atores, pois, 
podia parecer que não estava dando importância ao espetáculo e àquele momento. Mas, depois, observando e me baseando em outras vivências, entendi que me deixar desarmada, tendo que pedir favores ou empréstimos aos outros atores, era um modo de me colocar em contato com eles de um modo menos formal, já entrando em uma certa intimidade e, ainda, em desvantagem.

O camarim de Slava, Elena e seus filhos era separado, ficava na parte superior, próximo ao restaurante. Artem e Stanislav tinham camarins pessoais, eram atores que gozavam de um certo respeito dos outros atores, pelo tempo que faziam parte da trupe. Os dois tinham, com eles, a família, esposas e filhas.

Apesar de se tratar de uma superprodução, as relações em família se mantém. Não me refiro somente às relações consanguíneas, mas das relações que se estabelecem entre os integrantes do grupo. Um dos filhos de Slava faz parte do elenco, o outro cuida da parte sonora, sua esposa, Anna, é a secretária e Elena cuida da parte administrativa. Talvez tenham exercido ou exercem outras funções, mas as que percebi, naquele período, foram essas. As famílias de Artem e Stanislav convivem com a trupe. A filha de Artem, muitas vezes, entra no espetáculo, no entract, e no final, vestida com uma roupa amarela, igual a de Slava e de Artem. A esposa de Stanislav, Larissa Lebedeva e sua filha, Anna Warkki, também trabalham com teatro e dança, algumas vezes também participam do espetáculo. Larissa tem um trabalho primoroso com dança, e os três (Stanislav, Larissa e Anna) possuem um trabalho lindo de teatro de rua, e é emocionante vê-los trabalhando. Posso dizer que Larissa foi a primeira pessoa a se aproximar de mim, ela fala um pouco de francês, me observava durante o espetáculo, algumas vezes me dava dicas sobre o caminhar, o olhar, com uma delicadeza e leveza comovente. Stanislav não falava nada de francês, mas a primeira comunicação foi estabelecida através da máscara, nas coxias. Jogávamos enquanto esperávamos a hora de entrar, brincávamos, nos divertíamos com pequenos gestos e olhares. Stanislav tem um clown com um lado cruel bem acentuado - é maravilhoso!

Retornando ao dia de minha estreia no espetáculo, por volta de uma hora e meia antes, os atores começam a se arrumar. Não há aquecimento. Não há passagem de cenas e, principalmente, não existe uma relação visível com a Máscara - o nariz é um acessório. Fiquei me perguntando como era aquela relação, qual era o mecanismo para o estado de Máscara acontecer?

Os atores terminavam de se preparar e subiam para o palco. Terminei de me preparar, observei como se organizavam para caminhar com aquele figurino enorme (sapatos grandes para frente, chapéu com grandes abas para os lados e casaco arrastando) para me locomover também. Aprendi como conseguir andar e no que tinha que prestar atenção para poder me locomover. Subi para as coxias ao lado do palco.

Estavam todos juntos com Slava, ele me chamou, disse que era para eu ficar nas coxias observando todo o espetáculo e que eu entraria no entract e no final. Como no circo, o novato começa com pequenas participações.

Entrei e me coloquei ao lado da porta, onde podia ver o palco de um ângulo diagonal de fundo. Logo Sasha veio me pedir que eu me colocasse na primeira coxia, no canto, para ver o espetáculo mais de frente, e me colocou exatamente no lugar em que eu deveria permanecer. Ali fiquei, observando a movimentação das coxias, enquanto o espetáculo não começava. Para mim era estranho ver os atores com as Máscaras e agindo como se nada estivesse acontecendo, nem mesmo se 
aquecerem ou passarem as marcações de entrada e saída. Em compensação, os técnicos cuidavam da maquinaria, revisavam tudo, pareciam mais preocupados que os atores. Depois pude entender essa relação dos técnicos (Dmitry Sakhalov, Dmitri Syrovatskiy e Vania (Ivan) Yaropolski) com o espetáculo e atores, na qual entrarei mais adiante.

As luzes se apagaram, os atores que estavam lá fora entraram, a música começou, Slava entrou nas coxias, passou por trás da cortina do fundo e foi para o lado oposto do palco, na primeira coxia, em frente à que eu estava. Então a concentração começa. Segundos antes de entrar em cena, Dmitry segura a corda que Slava usa na cena, colocada exatamente do modo como ele deve entrar - Slava pega a corda e quando coloca o pé no palco, em que "toma consciência" da presença do público, do espetáculo acontecendo, o corpo muda e o estado de máscara acontece. O corpo muda, a energia muda, a presença é outra, entra em cena o Clown e todos do elenco, novatos e antigos observavam a Máscara em cena. Para mim, um novo aprendizado - a consciência do evento em si, do olhar do público, como instaurador do estado de Máscara.

O espetáculo avança, e nas coxias acontece uma engrenagem. Todos sabiam seus lugares e onde deveriam colocar-se em cada cena, para que os atores, cada qual na sua hora, tivessem espaço livre para entrar, sair e arrumar acessórios.

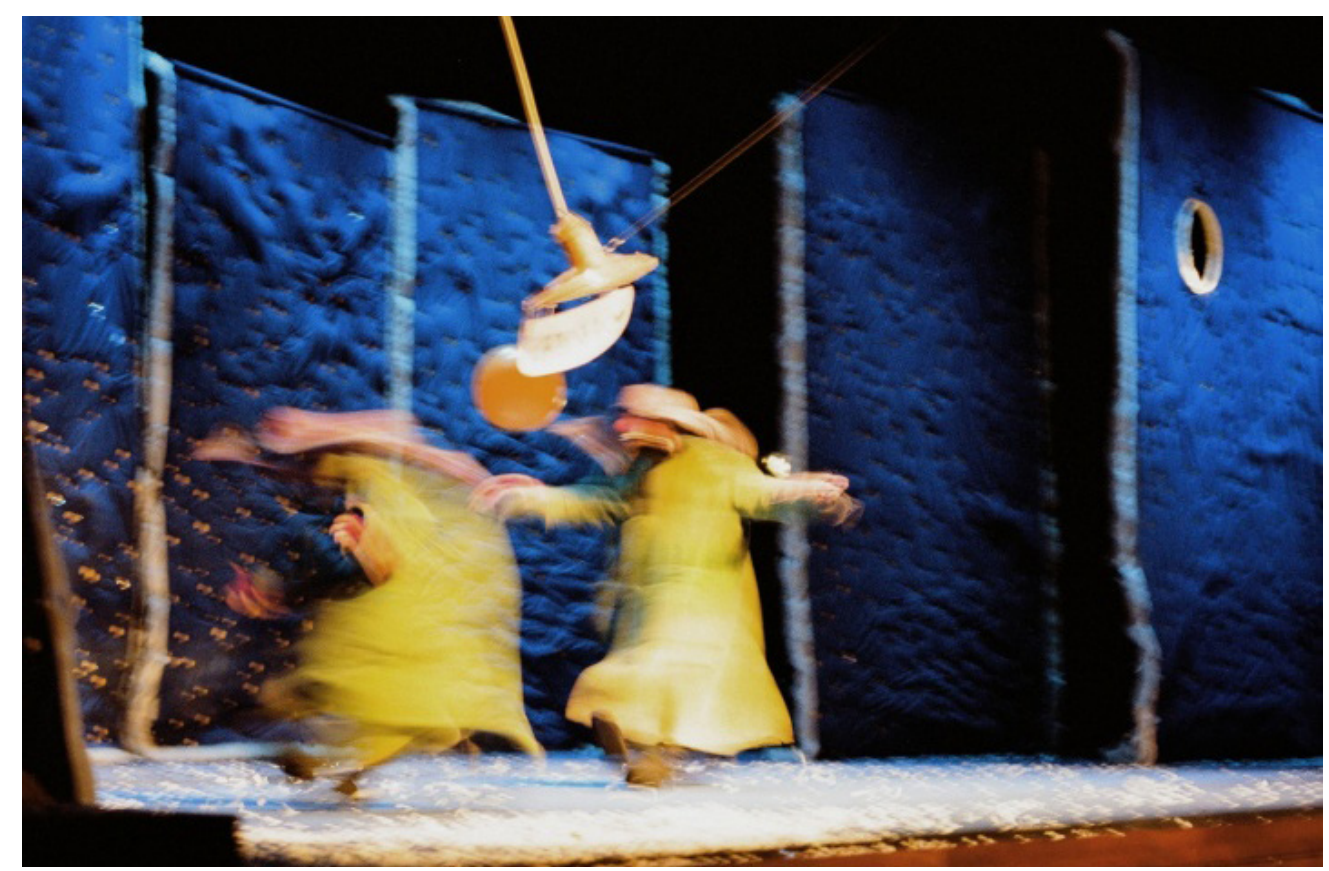

Figura 3 - Direitos reservados - Espetáculo: SlavaSnowShow Cena: Entract. Fonte:

Chegou a hora do entract, eu tinha que entrar, mas ninguém me disse o que eu deveria fazer, somente sabia que tinha que entrar. Os atores iam entrando, e eu me preparando para entrar. Robert passou por mim, entrou em cena, parou, olhou para trás e me estendeu a mão. Eu olhei para ele, inicialmente fiquei aliviada, depois fiquei nervosa, por entrar com alguém que já conhecia tudo do espetáculo. Segurei a mão 
de Robert e entrei em cena. Uma vez que estava no centro do palco, Robert soltou minha mão, mas me acompanhava com o olhar. Desceu das escadas e, com o olhar, me chamou. Fui seguindo-o durante o entract. Robert foi meu guia para aquela primeira entrada. Agora, era esperar pelo final, e o final chegou. E era chegada a hora de entrar novamente. Sasha indicou que eu entrasse e me colocasse em algum lugar do palco, simplesmente olhasse para o público, sem nenhuma reação. Entrei, fui para o fundo do palco, parei e permaneci olhando. Pude vislumbrar uma das cenas mais lindas do espetáculo: o encontro do público com as bolas.

Percebi que, o que acontece durante o espetáculo, é um movimento que faz brotar a vontade de brincar em todo o espectador, e a bola se transforma no objeto de desejo de cada um. É uma vontade de brincar que vê-se no olhar e no gesto de esticar todo o corpo para alcançar e tocar a bola, jogando para outra pessoa ou para um dos clowns. Não é um desejo de pegar a bola, é um desejo de jogar, de tocar e trocar com outra pessoa. Quando as bolas saem do palco para a plateia, é como se o público pudesse voltar a ser criança, ao menos por uns segundos. Vi adultos e crianças disputando a bola que chegava pelo ar, com a mesma intensidade e vontade. Todos tinham a mesma idade, todos eram crianças ansiosas por brincar. Claro que sempre tem aqueles que se seguram, que não querem se deixar levar pela euforia que toma conta, mas não tiram os olhos das bolas e, na medida que o público vai se dissolvendo, até mesmo esses arriscam um toque, para parecer que estão querendo ajudar, devolvendo as bolas para o palco.

Olhando o final do espetáculo do palco e da coxia, queria entender o que acontecia com o público, pois acontece uma transformação. É claro que o público entra no teatro com uma predisposição à participação no espetáculo, eles aceitam correr o risco de serem molhados, sujados e outras possibilidades de importunações, mas alguma coisa acontece no final do espetáculo. Ficava investigando, observando palco e público durante todo o espetáculo para descobrir. Além da predisposição do público, tinha ainda os números que envolvem o público e o clima de jocosidade que Slava trabalha em todo o espetáculo, aguçando a imaginação pueril do público, deixando latente a vontade de brincar. Mas onde estava o momento da permissividade do público? Porque existia a permissão e a compreensão que aqueles clowns podiam agir daquela maneira, pois são clowns; mas quando o público se permite a vivenciar um pouco daquela brincadeira de clowns? A resposta veio na forma de uma pergunta: por que Slava tira a máscara/nariz no final do espetáculo, aparecendo diante do púbico sem ela, enquanto todos os outros palhaços continuam com a máscara/nariz? Observando a ação dele e a reação do público, pude perceber que a ação de tirar a máscara/nariz diante do público era a chave para a o público se permitir agir, em alguma instância, como aquela pessoa que está no palco brincando, e que naquele momento não era mais um clown. Tirando a máscara Slava torna-se igual ao público e isso é o que ele necessita para deixar aflorar a vontade de brincar e agir dentro do espetáculo, o qual pensa ter acabado. mas que continua, porém, com sua participação. E, nesse momento, a plateia se torna o palco e os clowns, no palco, são os espectadores.

A indicação para nós atores nesse momento final, com as bolas, é que, depois de as lançarmos para o público, após jogarmos com os espectadores, é necessário parar e olhar o que está acontecendo - o espetáculo passa a ser na plateia e nós os espectadores. Depois de um tempo, começa-se a guardar as bolas, as colocamos repousadas sobre o palco, construindo uma paisagem de clowns e bolas, sob uma 
luz que passa do amarelo ao azul. Nesse momento, a indicação é para permanecermos no palco até o público ir embora, porém, nem sempre isso acontece. As vezes o público permanece no teatro, dando a impressão de que não querem perder contato com aquela atmosfera criada. Então, entra um som imitando um trovão e após, um blackout - é a marca para sairmos de cena -, e quando a luz retorna, estão no palco somente as bolas.

No primeiro dia, terminando o espetáculo, desci e fui tirar o figurino. Oleg Sosnovikov me emprestou demaquilante. Deixei o figurino dobrado em cima de uma cadeira, em frente ao meu lugar no camarim, me despedi e fui pegar o metrô.

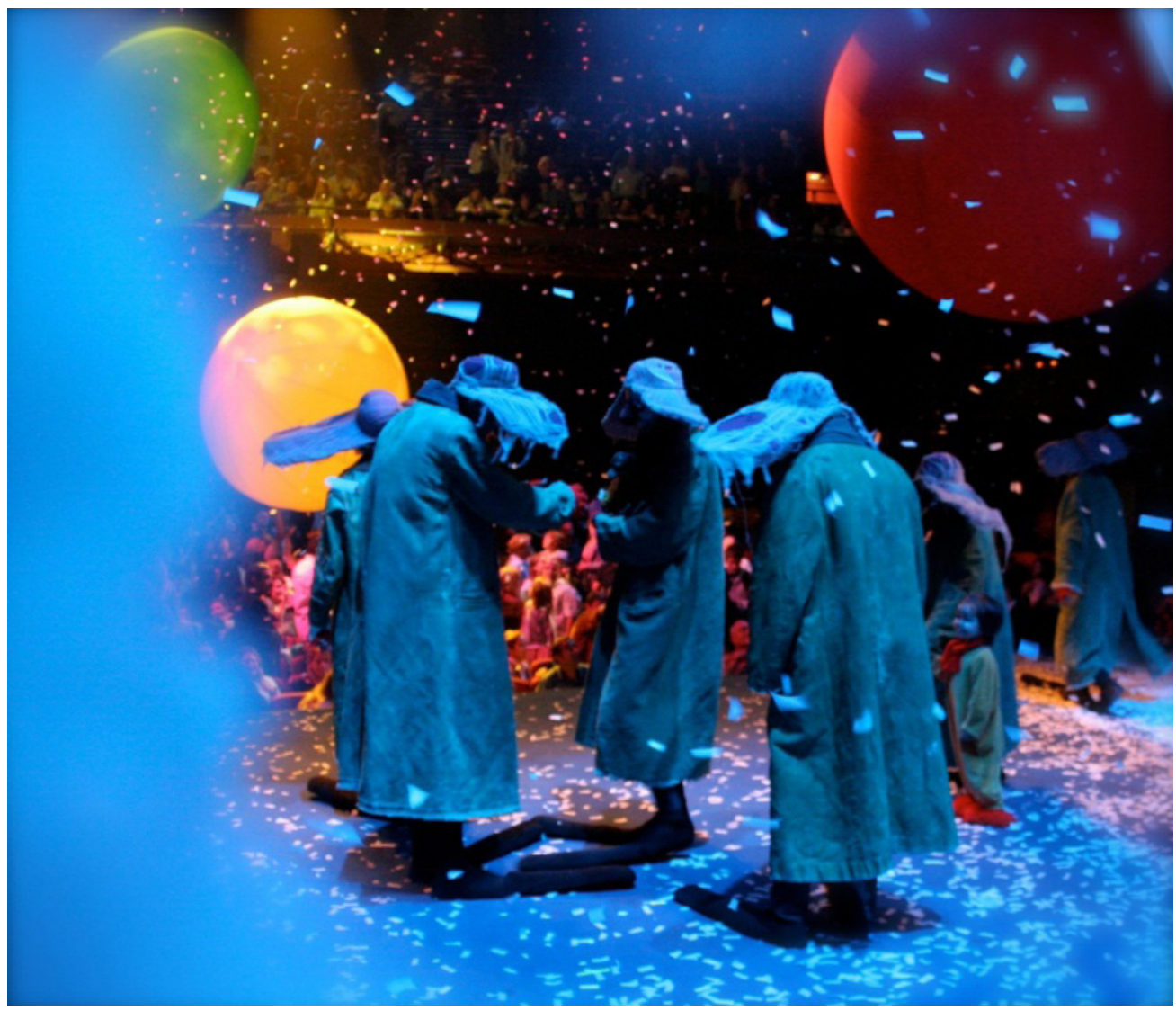

Figura 4 - Direitos reservados - Espetáculo: SlavaSnowShow

Cena: Final com o público. Fonte:

No segundo dia, cheguei algumas horas antes do espetáculo e fui organizar meu estojo de maquiagem, pois tinha comprado tudo o que precisava: maquiagem, esponja e demaquilante. Sentia uma alegria infantil de estrear material escolar. Os atores iam chegando aos poucos, organizavam suas coisas e depois subiam ao restaurante. Me convidaram para jantar e tentei explicar que não conseguia comer nada antes de qualquer apresentação. Mas nenhum dos atores que estavam, naquele momento, compreendia francês. Eles foram subindo ao restaurante e eu fiquei me arrumando.

Os atores foram retornando do restaurante, aos poucos. Meia hora antes do espetáculo, Elena desceu até o camarim, veio em minha direção e disse que, naque- 
le dia e no posterior, eu deveria apenas assistir ao espetáculo. Retirei o figurino e o dobrei, retirei a maquiagem e fui para o hall dos atores, próximo às coxias. Slava me disse para observar os atores, suas ações e tempos. Concordei e esperei que me dissessem onde eu deveria ir para observar o espetáculo.

Todos falavam e se divertiam. O sinal foi dado, todos entraram, se colocaram em seus lugares e um técnico me levou para a plateia - terceiro andar, de frente para o palco. Prestei atenção em tudo - um espetáculo primoroso, atores com domínio técnico, a dramaturgia encantadora e gags tradicionais que ganham nova roupagem.

Depois do espetáculo, desci, me despedi de Elena e perguntei a que horas deveria chegar no outro dia. Estava acontecendo uma festa de aniversário. Elena me convidou para ficar, mas como não tinham me convidado anteriormente, preferi sair, para não parecer que estava impondo minha presença.

No terceiro dia, cheguei e esperei no hall dos atores e novamente Slava me disse para prestar atenção nas ações e tempo dos atores. Após soar o primeiro sinal, me dirigi para o mesmo lugar da noite anterior. Dessa vez, fiquei mais atenta às entradas e saídas dos atores. Como tinha visto a movimentação dos técnicos, nas coxias, no primeiro dia, tinha o conhecimento do que estava acontecendo por trás da cortina, então, tive a compreensão de como a equipe se engrenava - uma harmonia que fazia a diferença. Antes do espetáculo, os atores não se preocupavam com os acessórios, eram os técnicos que verificavam tudo e preparavam com exímio cuidado, na hora da cena, o ator estava pronto para entrar e os técnicos estavam em seus postos, impecáveis, com tudo calculado e preparado. A equipe técnica por trás das cortinas é outro now show. A mesma confiança que os artistas de circo têm nos técnicos que revisam a maquinaria do trapézio, as travas de segurança e as redes, os atores de SlavaSnowShow têem em seus técnicos. A atenção e cuidado que Dmitri Syrovatskiy, Dmitry Sakhalou e Ivan Yaropolski têm com o espetáculo é admirável. Todos os dias estão no palco horas antes do espetáculo, revisando, testando, calculando tudo. Durante o espetáculo, prestam atenção em tudo. Observam como a cena está andando e, muitas vezes, conversavam entre si sobre a cena, apontavam e gesticulavam, como no ritmo da cena ou imitando algum movimento, principalmente quando acontecia a substituição de Slava por um de seus "sósias".

Mais adiante falarei com mais precisão desse ponto; agora, só preciso dizer que assisti e participei do espetáculo SlavaSnowShow com Slava fazendo seu papel (de macacão amarelo) e com outros quatro atores fazendo seu papel: Artem Zihmo, Robert Saralp, Oleg Lugovskoy e Onofrio.

SlavaSnowShow se transformou em uma superprodução, porém, de uma forma generosa para com os atores e com olhos para o mercado - pois o teatro se tornou mercado desde que a primeira companhia dell'arte se estruturou, em 25 de fevereiro de 1545, em Padova, região de Trento (TESSARI: 1981). Slava construiu SlavaSnowShow em quadros, uma série de cenas e gags que podem ser apresentadas separadamente e em ordem diversa. A dramaturgia segue a ideia dos números de circo, ou seja, cada cena é independente, dando ao espetáculo a possibilidade de uma versatilidade, em relação a esta dramaturgia, podendo ser colocada em qualquer ordem - e isso acontecia. Como, nesse espetáculo, Slava trabalha com a repetição de figuras da tradicional dupla de clowns "Branco e Augusto"2 - o primeiro é mais

2 Para os leitores que se interessarem mais sobre "Branco e Augusto", ler: BURNIER, 2001; FERRACINI, 2001; 
identificável com o clown vestido de amarelo e o segundo com os clowns vestidos com um grande casaco verde, grandes sapatos e chapéu preto de abas -, os números não são presos à "atores/personagens", e as cenas são as grandes estrelas do espetáculo. A generosidade, e também a grande empreitada mercadológica, é que o espetáculo não necessita dele ou de qualquer outro ator, para acontecer. O espetáculo necessita de bons atores, preparados com técnicas de corpo, com precisão e perseguidores da perfeição, de atores que saibam todos os números muito bem.

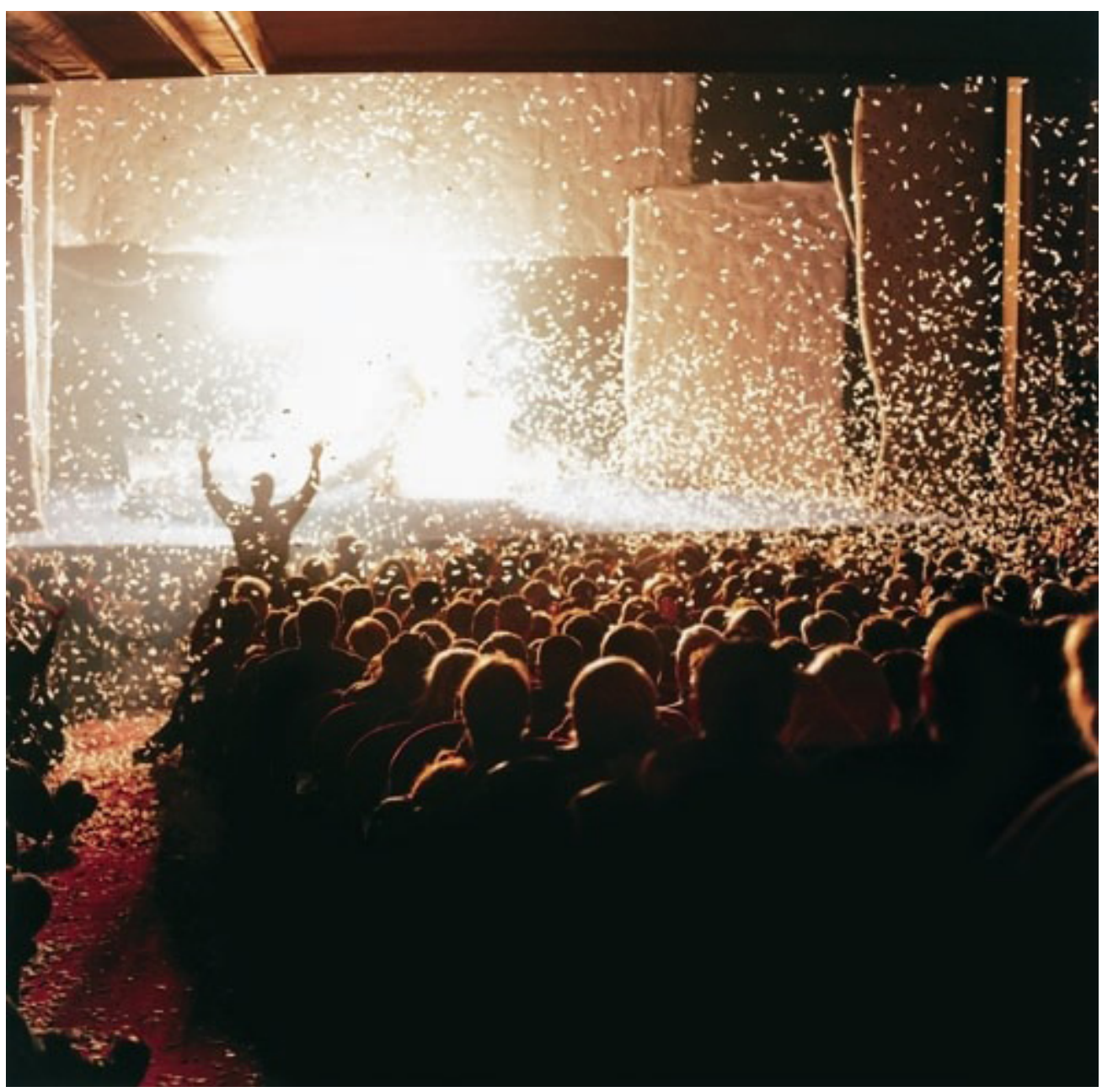

Figura 5 - Direitos reservados - Espetáculo: SlavaSnowShow Cena: Tempestade. Fonte:

A metodologia encontrada por Slava para que o espetáculo tenha sempre aquele efeito de novidade, não somente para o público, mas para os próprios atores é uma estratégia muito eficaz. Como os atores sabem as entradas e saídas, cenas e possibilidades de jogo de cena de quase todos os números/cenas, ele troca os atores de lugar. Fiquei durante muito tempo fazendo somente o entract e o final, mas 
todo dia tinham coisas diferentes para se jogar com o público e, desse modo, Slava me testava, para ver se eu estava sempre prestando atenção no espetáculo.

Da metade do mês de dezembro até janeiro, o espetáculo acontecia em Paris e em Londres. como disse, Slava tinha alguns sósias que faziam o espetáculo no lugar dele (vestido com a roupa amarela); assim, alguns dias da semana Slava não aparecia no teatro, pois estava em Londres, e depois retornava. Porém, uma coisa que entendi, é que Slava prima pela qualidade de seus espetáculos. Ficava pensando no cansaço que ele ficava, pois estava em um ritmo de viagem e apresentações - como, então, mantinha a qualidade do espetáculo? Outra coisa que aprendi, é que, como em família, ele confia nos atores com quem trabalha, mas, não bastava só isso para manter a qualidade do espetáculo. Um dia, durante o entract, em um relance, meus olhos cruzaram o olhar de Slava que estava no meio do público, avaliando o espetáculo e os atores do ponto de vista do espectador, prestando atenção no palco e no público.

Nos dias em que Slava fazia o espetáculo, era muito interessante. Todos sempre observavam com muita atenção as cenas, inclusive os técnicos. Perceber o que acontece durante o encontro deste profissional com o público, o efeito que a presença dele causa e o jogo que estabelece com o público, é um grande aprendizado.

Observei muito a equipe e a forma com o Slava organizava as apresentações como do espetáculo: todos tinham seus "números", aquele que repetia mais vezes, mas, alguns dias Slava, chamava os atores e (em russo) re-organizava o espetáculo, trocando-os de lugar. Como falava em russo, eu não entendia, ficava prestando atenção nas gesticulações, nas passagens de pensamento/gestos dos atores para tentar entender onde cada um iria se re-locar, em que número e em qual papel, então durante o espetáculo, podia perceber como todos sabiam os números de modo categórico. Mas ele também se preocupava em perceber se o novato (no caso, eu) estava prestando atenção no espetáculo, se estava assimilando todas as informações. E muitas vezes Slava mudou a marcação dos números em que eu fazia parte, no entract, sem ninguém me avisar. Como sempre estava atenta, mesmo não sabendo da combinação (pois era feita em russo), quando a primeira ação da cena mudava, eu já sabia que deveria estar em alerta e perceber como iria se desenvolver o restante da cena e seguir o fluxo.

Aos poucos, fui percebendo que os atores também ajudavam na técnica, em momentos mais ligados à cena, como encher as bolas, jogar papéis picados no ventilador, colocar móvel no palco - e aos poucos foram me introduzindo nessas funções, também, primeiro em pequenas ações, como colocar as "asas" e entregar o lampião aceso a um dos atores, quando ele passava: ele saía de uma cena, com o figurino normal (casaco verde, chapéu preto etc), pela coxia dos fundos e entrava pela coxia do meio, com asas e segurando um lampião. Depois, foram adicionando ações mais "complexas ou delicadas", como colocar móvel em cena durante o black -out, baixar acessório em um sistema de fios de um lado do palco e depois voltar para o outro lado para a entrada ou para auxiliar em outro detalhe técnico. O modo como os atores são envolvidos nessa técnica e nas cenas é de forma crescente, as informações primeiro são absorvidas pela visão, atenção/percepção e depois pela ação. Desse modo, não acontece uma avalanche de informações, tudo vai sendo absorvido sistematicamente. Certamente, esse também é um modo de manter os atores em alerta, pois estão sempre tendo "novas experiências" - re-locando os atores em posições/papéis diferentes nos números ou realizando funções diferentes na técnica. 


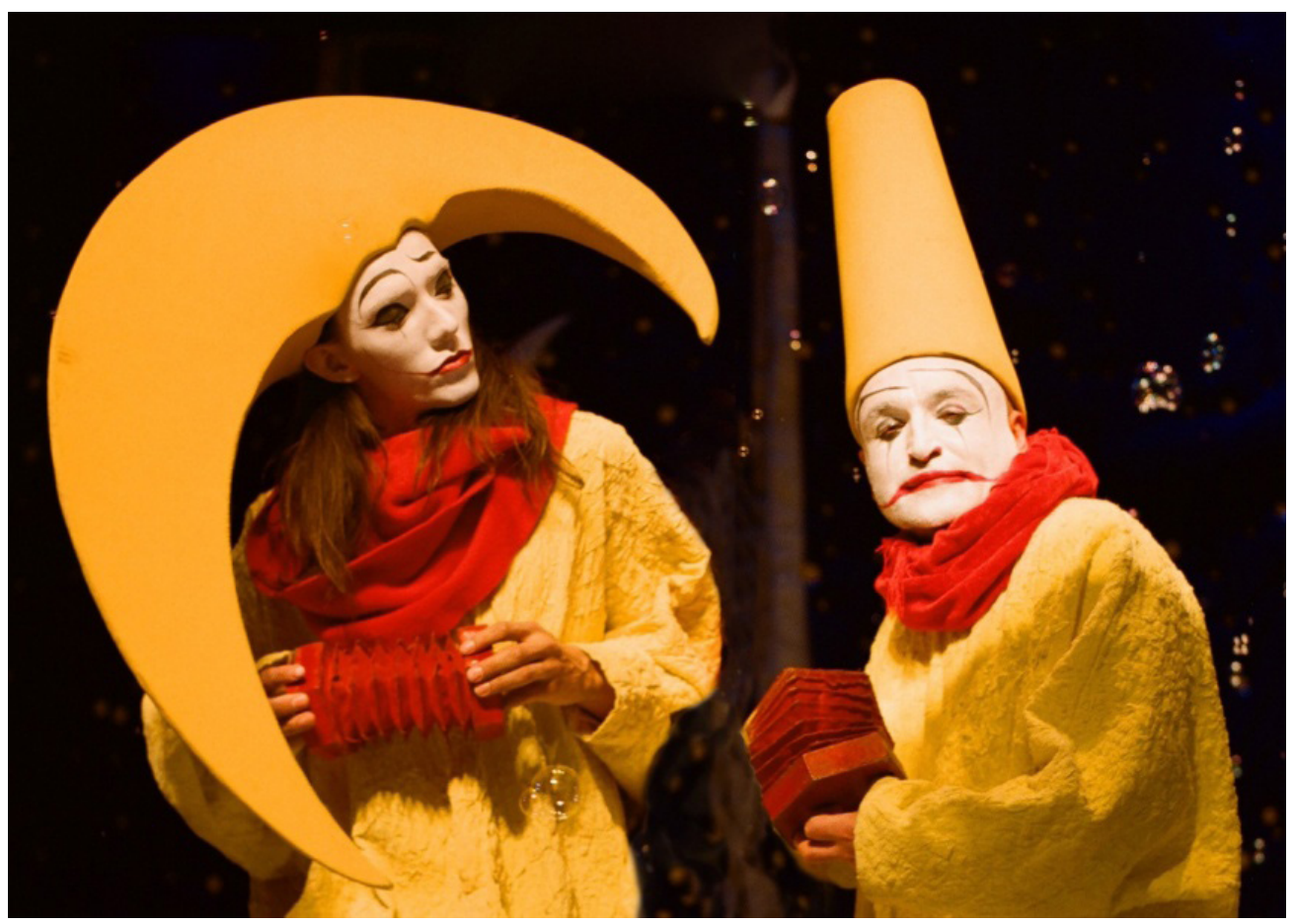

Figura 6 - Direitos reservados - Espetáculo: SlavaSnowShow

Cena: Blue Canaris. Fonte:

Slava se preocupava para que eu entendesse o conjunto do espetáculo. Em um certo momento da temporada, Sasha veio me dizer que eu deveria me colocar na coxia do outro lado do palco. Perguntei quem o ajudaria com os acessórios, pois eu o ajudava em uma entrada e saída de cena, mas ele disse que não me preocupasse. Então, comecei a assistir as cenas e fazer minhas entradas pelo lado esquerdo do palco.

Fazíamos uma sessão do espetáculo de terça a sexta, durante os finais de semana fazíamos duas sessões por dia e na segunda-feira, tínhamos uma "pausa".

Na medida em que eu ia ganhando segurança com o espetáculo, Sasha e Artem teciam comentários para me ajudar na movimentação e jogo com o público. Esse primeiro contato foi muito intenso e, inicialmente, solitário. Após um tempo, as relações foram se destensionando, e cada vez mais fui sendo integrada a outros números. Devo dizer que a emoção maior foi quando entrei no número Blue Canaris: um número de três clowns, que cantam/dublam uma antiga canção italiana. Dois clowns fazem a mimeses de estar tocando um pequeno acordeom e o clown do meio os segue, descompassado, caçando bolinhas de sabão com uma rede de caçar borboletas. Ficava, e fico, encantada toda vez que vejo esse número; quando o pude fazer, parecia que tinha um vulcão dentro de mim - um vulcão de bolinhas de sabão.

A metodologia com a qual Slava introduz novos clowns dentro de um espetáculo é, sem sombra de dúvida, exaustiva. Não do ponto de vista físico, mas psicológico. Ele trabalha com a vontade e perseverança do ator. Os aspectos familiares que se mantêm, mesmo dentro de uma super produção, é uma forma de deixar latente a tradição do circo. A vontade e seriedade com que os atores executam o espetáculo e como os técnicos encaram o dia a dia de temporada, é admirável e mais incrivel 
ainda, é ver e sentir o efeito do espetáculo sobre o público.

Penso que não seria o caso de fazer um relato cronológico das experiências vividas, mas deixo aqui, algumas observações e reflexões realizadas a partir das vivências que tive com a família SlavaSnowShow.

\section{Referências}

BURNIER, Luis Otávio. A arte de ator: da técnica à representação. Elaboração, codificação e sistematização de técnicas corpóreas e vocais para o ator. Campinas: Editora da UNICAMP, 2001.

FERRACINI, Renato. A arte de não interpretar como poesia corpórea do ator. São Paulo: Unicamp, 2001.

FO, Dario. Manual mínimo do ator. Tradução de: Lucas Baldovino, Carlos David Slak. São Paulo: Ed SENAC, 1999.

TESSARI, Roberto. Commedia dell'Arte: La Maschera e l'Ombra. Azzate: Mursia, 1981.

VIGANO, Antonio. Nasi Rossi il clown tra circo e teatro. Montepulciano: Del Grifo, 1985. 